\title{
Yucca review-board head quits in face of impartiality charges
}

\section{Geoff Brumfiel, Washington}

The embattled head of a review board for the proposed Yucca Mountain nuclearwaste repository has resigned. His critics had charged that he was too closely tied to the nuclear industry.

Michael Corradini, a nuclear engineer at the University of Wisconsin at Madison, announced his resignation from the Department of Energy's Nuclear Waste Technical Review Board on 30 December. His public support for the Yucca Mountain Project and his pursuit of nuclear research had led project opponents, including all five members of Nevada's congressional delegation, to question his impartiality and call for his resignation.

The review board is set up as an independent body, and has been charged with evaluating the energy department's licence application for the Yucca project (see Nature 418, 262; 2002). It has long been considered an impartial judge of technical questions, says Judy Treichel, executive director of the Las Vegas-based Nevada Nuclear Waste Taskforce, which opposes the project.

Treichel claims that this record of impartiality was threatened in June 2002, when the Bush administration appointed Corradini as chair. Corradini has testified to Congress in support of the project. He also continued to receive funding from the energy department for his research on nuclear power - something other board members say they have stopped doing. The congressional delegation sent a letter to President George Bush on 25 February 2003 calling for Corradini's resignation.

Faced with such local opposition, the nine other board members wrote to Corradini in May, asking him to go.

Corradini at first refused to step down, saying that he would not give in to "political pressure". Nor did he back away from support of the project, co-authoring a newspaper article last October that stated that "Yucca Mountain is doable".

"It was a bit like a judge making a statement about the verdict before the trial has begun," says Norman Christensen, an ecologist at Duke University in North Carolina and a board member.

Corradini disputes that. "I don't think that me stating a fact makes me unacceptable, and I also don't think that makes me lack objectivity," he says.

Nonetheless, he concedes that opposition to his appointment had made it difficult for the committee to function, and so offered his resignation.

\section{Safety concerns prompt US ban on dietary supplement}

Jonathan Knight, San Francisco

The US government is to ban the popular dietary supplement ephedra because of mounting evidence of its toxicity. The ban has been welcomed by publichealth advocates, but some critics have branded it an overreaction to adverse publicity about the drug.

Some 12 million Americans take diet pills or consume energy drinks laced with Ephedra sinica a Chinese medicinal herb containing stimulants known as ephedrine alkaloids. But the 1994 Dietary Supplement Health and Education Act prevents the Food and Drug Administration (FDA) from enforcing safety studies for herbal supplements, as long as the product does not claim to cure any disease. Dozens of US companies sell ephedra-containing products.

But in a press release on 30 December, the FDA said that ephedra had been "conclusively linked to significant and substantial adverse health effects like heart problems and strokes". Once the agency's ruling is published, manufacturers will have 60 days to take their products off the market.

Since 1994, the FDA has received hundreds of complaints of adverse reactions to ephedra, ranging in severity from heartburn to death. But because the herb is so popular, it has been hard to determine which of the many effects reported were actually caused by the drug.

"Heart attacks happen anyway, and millions of people take ephedra, so these two universes will intersect," says Paul Shekelle, director of the Southern California Evidencebased Practice Center in Santa Monica. The centre is run jointly by five medical research centres and the Rand Corporation, a nonprofit consultancy that assesses technical problems.

In 2001 the FDA asked the centre to analyse all available data on ephedra. Its conclusions, published last March (P. G. Shekelle et al. J. Am. Med. Assoc. 289, 1537-1545; 2003), linked the substance to minor side effects, but was less clear-cut on its connection with more serious effects such as heart attacks.

Of 18,000 adverse-event reports made either to the FDA or to an ephedra manufacturer during 2000, only 21 contained sufficient information to conclude a probable role for ephedra, and only two of these were reports of deaths. "This was not a slam dunk in either direction," Shekelle says.
Nevertheless, several high-profile deaths have raised public awareness of ephedra's potential risks. Last February, baseball pitcher Steve Bechler died of heat stroke while training for the Baltimore Orioles in Florida. The coroner concluded that ephedra, which Bechler had been taking for a weight problem, was a significant factor. And the deaths of Illinois high-school athlete Sean Riggins in 2002 and Minnesota Vikings tackle Korey Stringer in 2001 were also linked to ephedra. None of these was included in the data Shekelle reviewed.

Critics suspect that this adverse publicity has been a key factor leading to the ban. "We should rely more on scientific data than anecdotes in setting public-health policy," says Carol Boozer, an obesity researcher at St Luke's-Roosevelt Hospital Center in New York. And Steven Karch, a cardiac pathologist in San Francisco who studies stimulant abuse, says he has found no evidence that ephedra has played a role in anylocal death in the past decade. "We just don't see it," he says.

The FDA has not yet detailed its case supporting the ban, but says it will publish the ruling within a few weeks. Meanwhile, consumers are stocking up and there have been reports of health stores selling out of ephedra as fast as they can fill the shelves. 